\title{
A cluster of three cases of botulism due to Clostridium baratii type F, France, August 2015
}

H Tréhard ${ }^{1}$, I Poujol ${ }^{1}$, C Mazuet ${ }^{2}$, Q Blanc ${ }^{3}$, Y Gillet ${ }^{4}$, F Rossignol 5 , M Popoff ${ }^{2}$, N Jourdan Da Silva ${ }^{6}$

1. French Institute for Public Health Surveillance, InVS, Department of Coordination of Alerts and Regions, Regional office in Rhône-Alpes, Lyon, France

2. National Reference Centre (NRC) for anaerobic bacteria and botulism, Institut Pasteur, Paris, France

3. Valence Hospital Centre, Intensive care unit, Valence, France

4. Hôpital Femme Mère Enfant (HFME), Lyon paediatric hospital, Intensive care unit, Lyon, France

5. District Veterinary Services (DDPP), Regional office in Drôme, Valence, France

6. French Institute for Public Health Surveillance, InVS, Department of Infectious Disease, Saint-Maurice, France

Correspondence: Hélène Tréhard (Inta@hotmail.fr)

Citation style for this article:

Tréhard H, Poujol I, Mazuet C, Blanc Q, Gillet Y, Rossignol F, Popoff M, Jourdan Da Silva N. A cluster of three cases of botulism due to Clostridium baratii type F, France, August 2015. Euro Surveill. 2016;21(4):pii=30117. DOI: http://dx.doi.org/10.2807/1560-7917.ES.2016.21.4.30117

Article submitted on 11 January 2016/ accepted on 28 January 2016 / published on 28 January 2016

A cluster of three cases of food-borne botulism due to Clostridium baratii type $\mathrm{F}$ occurred in France in August 2015. All cases required respiratory assistance. Consumption of a Bolognese sauce at the same restaurant was the likely source of contamination. Clostridium baratii was isolated both from stool specimens from the three patients and ground meat used to prepare the sauce. This is the second episode reported in France caused by this rare pathogen.

\section{Description of the cases}

In August 2015, two clinically suspected cases of botulism (having both gastrointestinal and neurological symptoms such as dysphagia, diplopia or blurred vision, and progressive paralysis) occurred within the same intensive care unit in France and were reported to the French public health authorities. Patients were from different households. Both had presented with gastrointestinal symptoms two days before hospital admission. Electromyography (EMG) showed a presynaptic block and cerebrospinal fluid (CSF) examination was normal. Both patients received a botulinum antitoxin $A B E$ treatment, four and five days respectively, after symptom onset.

One week later, a third clinically suspected case of botulism with gastrointestinal symptom onset within the same timeframe as the previous two was reported. This patient was initially admitted to a local paediatric unit and later transferred to intensive care unit with dyspnoea, dysphonia and global muscular weakness. He also presented blurred vision and bilateral mydriasis. A few days later, he was transferred to the regional paediatric intensive care unit because of clinical worsening. Guillain-Barré syndrome was initially suspected based on compatible symptoms, elevated CSF protein level, and a first EMG that did not show any presynaptic block (day 5 after symptom onset). Therefore, he was treated with Intravenous immunoglobulin as an atypical Guillain-Barré syndrome. A second EMG showed presynaptic block six days later (day 11 after symptom onset). Because of this late diagnosis and clinical improvement, this patient did not receive any botulinum antitoxin treatment.

None of the three cases had any gastrointestinal disease or invasive gastrointestinal procedure before illness onset.

All patients subsequently developed quadriplegia and respiratory failure requiring intubation and respiratory assistance between 24 and 48 hours after symptom onset. Median length of hospitalisation was 27 days (range: 16-38) and mean duration of intubation was 15.5 days (range: $9-25$ ). All patients recovered.

\section{Epidemiological, food and environmental investigation}

The patients were not related to each other. The only common food item was pasta with Bolognese sauce eaten by the three patients on the same day (lunch or dinner) at the same restaurant in late August. The mean duration from consumption of the suspected meal to symptom onset was 32 hours (range: $18-54$ hours) and neurological symptoms developed between 24 and 72 hours after consumption of the suspected meal.

One day after the notification of the first two cases (clinical suspicion), the implicated restaurant was inspected by the district food control authority (DDPP). Inspection revealed hygiene deficiencies in food manufacturing and storage according to good practice guidelines of the national food safety authorities. 
The National Reference Center for anaerobic bacteria and botulism analysis of 21 food samples, France, August 2015

\begin{tabular}{|c|c|c|c|}
\hline Food item & $\begin{array}{c}\text { Day of } \\
\text { sampling }\end{array}$ & $\begin{array}{l}\text { Presence } \\
\text { of toxin }\end{array}$ & $\begin{array}{c}\text { Presence of } \\
\text { Clostridium baratii }\end{array}$ \\
\hline Dried cured ham & $\mathrm{D}_{1}$ & Neg & $\mathrm{Neg}$ \\
\hline Anchovies & $\mathrm{D}_{1}$ & Neg & $\mathrm{Neg}$ \\
\hline Pesto & D1 & $\mathrm{Neg}$ & $\mathrm{Neg}$ \\
\hline $\begin{array}{l}\text { Ocean sauce } \\
\text { (seafood) }\end{array}$ & $\mathrm{D}_{1}$ & $\mathrm{Neg}$ & $\mathrm{Neg}$ \\
\hline Frozen ground meat & $D_{3}$ & Neg & Pos \\
\hline Curry chicken & $D_{3}$ & $\mathrm{Neg}$ & $\mathrm{Neg}$ \\
\hline Oil & $D_{3}$ & $\mathrm{Neg}$ & $\mathrm{Neg}$ \\
\hline Tomatoes & $D_{3}$ & Neg & $\mathrm{Neg}$ \\
\hline Onions & D3 & Neg & $\mathrm{Neg}$ \\
\hline Olive oil & $D_{3}$ & $\mathrm{Neg}$ & $\mathrm{Neg}$ \\
\hline Snails & D3 & $\mathrm{Neg}$ & $\mathrm{Neg}$ \\
\hline Leeks & $D_{3}$ & Neg & $\mathrm{Neg}$ \\
\hline Seafood & $\mathrm{D}_{3}$ & Neg & $\mathrm{Neg}$ \\
\hline $\begin{array}{l}\text { Defrosted ground } \\
\text { meat }\end{array}$ & D3 & Neg & Pos \\
\hline Capers & $D_{3}$ & Neg & $\mathrm{Neg}$ \\
\hline Tortellini & D3 & Neg & Neg \\
\hline Raviolini & D3 & Neg & $\mathrm{Neg}$ \\
\hline Smoked salmon & D3 & Neg & $\mathrm{Neg}$ \\
\hline Bolognese sauce $^{a}$ & D3 & Neg & $\mathrm{Neg}$ \\
\hline Oregano & $D_{3}$ & $\mathrm{Neg}$ & $\mathrm{Neg}$ \\
\hline Basque chicken & $D_{3}$ & Neg & Neg \\
\hline
\end{tabular}

Neg: negative; Pos: positive.

a Served after the suspected meal.

D1 represents Day 1, one day after the notification of the first two cases.

D3 represents Day 3, three days after the notification of the first two cases.

Samples of food at risk for botulism [1] were collected and sent to the National Reference Center (NRC) for anaerobic bacteria and botulism in Paris (Table). Two days later, although no leftover from the implicated Bolognese sauce was available, a second collection of food samples targeting sauce ingredients was performed (Table).

\section{Laboratory investigation}

The NRC evidenced toxicity in the serum samples of each patient (mouse bioassay) but could not confirm the identification of botulinum toxin type.

In early September, 13 days after symptom onset, $C$. baratii was identified at the NRC in the stool samples of the three patients by PCR and culture. Botulinum toxin $F$ was recovered from stool samples of two patients.

No neurotoxigenic Clostridium or toxin was identified in any of the food samples collected during the first inspection (conducted one day after the notification of the first two cases). However, both frozen and defrosted ground meat samples subsequently collected were positive for $C$. baratii but no toxin was detected (Table). In addition, all 34 meat samples collected from stored samples at the meat producer tested negative for $C$. baratii at the NRC.

\section{Public health measures}

One day after the second inspection, the implicated restaurant closed for stock renewal and environmental cleaning. No other consumers of Bolognese sauce were identified and no other botulism case linked to this restaurant was further reported despite the fact that the local emergency department was alerted by the local health authorities.

Trace-back and trace-forward investigation of the contaminated meat batch was conducted by the Ministry of Agriculture (DGAL) which issued a product recall. Although this batch had been distributed to different catering facilities since March 2015, no C. baratiirelated botulism case had been reported between March and August 2015.

\section{Discussion}

Food-borne botulism due to $C$. baratii type $\mathrm{F}$ is rare and only a limited number of cases have been reported worldwide [1-6].

The three cases reported here presented with severe symptoms and rapid progression towards respiratory failure and quadriplegia, although of shorter duration compared with C. botulinum-related botulism [4]. These clinical signs are similar to those described for type $F$ botulism cases [1-8]. A high level of protein in the CSF has also been described with botulism [7,9], which could lead to misdiagnosis.

The first two patients received type $A B E$ botulinum antitoxin four and five days respectively, after symptom onset. According to scientific advice on type $\mathrm{F}$ botulism, published by the European Centre for Disease Prevention and Control (ECDC), this treatment is expected to be ineffective for type F-related cases [1]. However, it has to be noted that these first two patients had both hospitalisation and intubation duration shorter than the third patient who did not receive any antitoxin. This difference could be due to other factors such as age, medical history, toxin amount ingested or other treatment.

The investigation identified the ground meat used to prepare the sauce as the most probable vehicle of $C$. baratii contamination. However, the ultimate source and mode of contamination of the meat remain unknown. No further case was identified in France during the shelf-life of the contaminated meat despite the wide distribution of the product, and the investigation of the producer's stored samples was negative.

No toxin was found in frozen and defrosted ground meat but the sauce eaten by the patients was not tested. Based on the restaurant inspection results (no 
temperature monitoring of stored preparations) and given the known conditions of toxin production, we can hypothesise that the botulinum toxin was produced during the sauce cooking process or storage. Indeed, preparations of a large volume of meat sauce by boiling for more than ten minutes and storage at room temperature for several hours are favourable conditions including anaerobiosis and substrate requirement for Clostridium growth and toxin production.

Suspected sources of $C$. baratii botulism reported in the literature included tomato meat sauce [5] and meat pit pies [6].

These types of food and ways of toxin production are not the most common in botulism, which is usually associated with home-canned products or dried pork products [1]. From 1981 to 2002, only nine cases of $C$. baratii botulism in adults were reported in the United States and a food source was implicated in only one $[4,5,7]$. Hypothesis of adult intestinal colonisation botulism was considered to explain unknown sources, particularly when gastrointestinal factors that can lead to alterations of the intestinal gut flora are associated $[4,7]$. Since 2002 , cases with unidentified sources have been reported in the United States [8,10-12].Finally, some of the unidentified sources for type $F$ botulism could be due to unusual sources such as meat.

This is the second $C$. baratii type $F$ botulism outbreak in France in less than one year [2,3]. Given that strains are centralised at the NRC, we can expect that any new case of type $\mathrm{F}$ botulism that may occur in the future, will be identified and notified. The type $\mathrm{F}$ botulism due to $C$. baratii represented an emerging issue in France and in Europe. Type $F$ botulism should be suspected in rapid onset and severe flaccid paralysis to promptly confirm the diagnosis with specific tests and rapidly administer appropriate antitoxin as treatment, when available. In Europe, the current botulinum antitoxin (capable of protecting only against type A, B, E toxins) is not appropriate in case of type $\mathrm{F}$ botulism, therefore the replacement with the heptavalent antitoxin could be considered.

Assuming that this type of botulism is emerging, it needs to be monitored with caution because investigations of new cases in France and Europe may bring new information about the origin of the contamination by $C$. baratii.

\section{Acknowledgements}

We thank Nathalie Ragozin (ARS Rhône-Alpes) and Ghislain Didier (ARS Rhône-Alpes) for epidemiological investigation and Christine Saura (Cire Rhône-Alpes), Jean-Loup Chappert (Cire Rhône-Alpes) and Mathieu Tourdjman (InVS) for their comments on the manuscript.

\section{Conflict of interest}

None declared.

\section{Authors' contributions}

Hélène Tréhard: Collecting data, literature review, wrote the first draft of the paper and reviewed the manuscript critically.

Isabelle Poujol: Collecting data, wrote the first draft of the paper and reviewed the manuscript critically.

Christelle Mazuet: Microbiological analysis, literature review and reviewed the manuscript critically.

Quentin Blanc: Clinical management of patients and reviewed the manuscript critically.

Yves Gillet: Clinical management of patient and reviewed the manuscript critically.

Frédérique Rossignol: Veterinary investigation and reviewed the manuscript critically.

Michel-Robert Popoff: Microbiological analysis, literature review and reviewed the manuscript critically.

Nathalie Jourdan Da Silva: Study conducted, wrote the first draft of the paper and reviewed the manuscript critically.

\section{References}

1. European Centre for Disease Prevention and Control (ECDC). Technical report. Scientific advice on type $\mathrm{F}$ botulism. Stockholm: ECDC; Oct 2013. Available from: http://ecdc. europa.eu/en/publications/Publications/botulism-scientificadvice-type-F-botulism.pdf

2. Castor C, Mazuet C, Saint-Leger M, Vygen S, Coutureau J, Durand $M$, et al. Cluster of two cases of botulism due to Clostridium baratii type F in France, November 2014. Euro Surveill. 2015;20(6):21031. DOI: 10.2807/1560-7917. ES2015.20.6.21031 PMID: 25695475

3. Mazuet C, Sautereau J, Legeay C, Bouchier C, Bouvet P, Jourdan da Silva N, et al. Characterization of the first Clostridium baratii strain responsible for an outbreak of botulism type $F$ in France. Journal of Clinical Microbiology \& Case Reports. 2015;1(1):8.

4. Gupta A, Sumner CJ, Castor M, Maslanka S, Sobel J. Adult botulism type F in the United States, 1981-2002. Neurology. 2005;65(11):1694-700. DOI: 10.1212/01. wnl.0000187127.92446.4C PMID: 16344510

5. Harvey SM, Sturgeon J, Dassey DE. Botulism due to Clostridium baratii type F toxin.J Clin Microbiol. 2002;40(6):2260-2. DOI: 10.1128/JCM.40.6.2260-2262.2002 PMID: 12037104

6. Lafuente S, Nolla J, Valdezate S, Tortajada C, Vargas-Leguas $\mathrm{H}$, Parron I, et al. Two simultaneous botulism outbreaks in Barcelona: Clostridium baratii and Clostridium botulinum. Epidemiol Infect. 2013;141(9):1993-5. DOI: 10.1017/ S0950268812002592 PMID: 23158693

7. McCroskey LM, Hatheway CL, Woodruff BA, Greenberg JA, Jurgenson P. Type $\mathrm{F}$ botulism due to neurotoxigenic Clostridium baratii from an unknown source in an adult.J Clin Microbiol. 1991;29(11):2618-20.PMID: 1774272

8. Sobel J, Dill T, Kirkpatrick CL, Riek L, Luedtke P, Damrow TA. Clinical recovery and circulating botulinum toxin type $F$ in adult patient.Emerg Infect Dis. 2009;15(6):969-71. DOI: 10.3201/ eid1506.070571 PMID: 19523306

9. Sonnabend WF, Sonnabend OA, Gründler P, Ketz E. Intestinal toxicoinfection by Clostridium botulinum type $\mathrm{F}$ in an adult. Case associated with Guillain-Barré syndrome.Lancet. 1987;1(8529):357-61. DOI: 10.1016/S0140-6736(87)91729-6 PMID: 2880164

10. Centers for Disease Control and Prevention (CDC). National Enteric Disease Surveillance: Botulism Annual Summary, 2005. Available from: http://www.cdc.gov/nationalsurveillance/pdfs/ botulism_cste_2005.pdf

11. Centers for Disease Control and Prevention (CDC). National Enteric Disease Surveillance: Botulism Annual Summary, 2007. Available from: http://www.cdc.gov/nationalsurveillance/pdfs/ botulism_cste_2007.pdf 
12. Centers for Disease Control and Prevention (CDC). National

Enteric Disease Surveillance: Botulism Annual Summary,

2013. Atlanta: CDC. 2013. Available from: http://www.cdc.gov/

nationalsurveillance/pdfs/botulism_cste_2013.pdf

\section{License and copyright}

This is an open-access article distributed under the terms of the Creative Commons Attribution (CC BY 4.0) Licence. You may share and adapt the material, but must give appropriate credit to the source, provide a link to the licence, and indicate if changes were made.

This article is copyright of the authors, 2016. 